\title{
Eskimo Shamanism
}

\author{
by ERIK HOLTVED
}

Shamans and shamanistic performances have been described from almost all parts of the Eskimo world, from the Pacific Ocean and Bering Strait to East Greenland, and to judge from the records it seems that the position and traditional functions of the shaman in general have had a rather uniform stamp all over this vast area. Apparently shamanism has been narrowly connected with Eskimo culture far back in time. Nevertheless certain characteristic differences found in the shamans' ways of exercising their practise indicate that the development has not proceeded along the same line in all cases. In this connection, however, it is necessary to take into consideration that the descriptions are not all of equal detail and value, and partly date from a period where shamanism was in decay. In a large number of cases, however, our knowledge is founded on eyewitness accounts, and among Canadian Eskimos in particular shamanism has been found living uninfluenced by the white man's civilization until only a few decades ago.

Generally speaking the task of the Eskimo shaman is to take charge of the relations to the supernatural powers that are supposed to interfere with human life. Thus it includes: first and foremost to procure game animals in times of failing luck in hunting, also to drive away wicked spirits, procure good weather, explore the future, and to cure sick people. In addition people might apply to the shamans in order to get strong amulets, songs or charms.

If hunger was impending because the game animals had disappeared the shaman could visit the deities who controlled the animals, the Moon-Man or the Sea-Woman (Sedna), and it would then appear that they had become angry and had withheld the animals because people had broken the prescribed rules. Having returned, the shaman would then try to find out the offender and have him or her confess. If he succeeded, and a penance had been im- 
posed on the offender-mostly prohibitions of eating certain parts of animals, or the like, the deity in question was supposed to have become satisfied.

In Greenland and Labrador the idea is met with that the offences became materialized as dirt (agdlerutit, or pitseete) in the hair of the Sea-Woman. The shaman had to struggle with her in order to be allowed to cleanse and comb her hair, and having succeeded, the Sea-Woman would promise to set the animals free that they might be hunted again.

On such occasions where the shaman acted on the behalf of the whole society he was not paid for his efforts. In all other cases, when his assistance was asked for, it would depend on a payment which according to circumstances might be rather great. This in particular applies to cases of sickness where the cause was supposed to be wicked magic, stealing of the soul, or some other supernatural reason including punishment for transgression of taboo rules. The patient could be cured by blowing, sucking, or extraction of some "object". In Greenland the shamans also had the more special task to destroy tupilaks, artificial monsters, that were sent out to pursue and kill a person.

It naturally follows that the shamans also played a prominent rôle at cultic ceremonies in places where such were held, as they more than others were familiar with the traditions, and experienced in dealing with the spirit world. Thus in Canada and Greenland, where the Sea-Woman cult was dominating it was totally in the hands of the shamans. In Alaska and with the Sibirian Eskimos, however, this was not necessarily the case. Often the ceremonies were here conducted by experienced old men; it might be the head of a family or a prominent hunter (umialik). If a shaman assisted, his position was rather that of an expert helper who also in such cases was paid for his services.

Thus Eskimo shamanism apparently had assumed a strongly professional stamp. But even if the shaman on some occasions can be said to have performed a kind of priestly function, yet he did not hold any in a proper sense official position within the society. Anyone, man or woman, who felt a vocation for it and possessed the necessary capability could appear before the public and act as a shaman, and obtain recognition as such. It was thus a purely personal matter. Only in relatively few instances we are told that a person could be predestined for the shaman's task. On Nunivak, according 
to Lantis, occasionally a son would become a shaman like his father, ${ }^{1}$ and from the Chugach Eskimos Birket-Smith reports that the dignity might sometimes go to a sister's son. ${ }^{2}$ Finally, a child might from birth be supposed to possess a particular power to withstand wicked supernatural forces, for instance if its parents had managed to keep it alive after having lost all their preceding children.

It can hardly be doubted that people in general had confidence in the shaman. He was felt to be a safeguard against hidden dangers. But exactly on account of his magic faculties and alliance with the spirit world he was also feared as a person with whom it might be risky to be on bad terms. On the other hand, also the shaman himself might run a risk, if he came to be suspected for abusing his power for bad purposes, which in some cases has resulted in his being killed. In the Alaska area in particular a suspicious attitude towards the shamans seems not to have been uncommon.

Furthermore, one might suppose that people's confidence could also be shaken by the disclosure of the shaman's often naive and badly disguised tricks and ventriloquism, but this seems not to have been the case. No doubt they were differently perceived when the nerves were strained under the impression produced by the séance, its darkness and mystery. In a corresponding way some songs attained their real power only when they were used on particular cultic occasions.

It is above all during the séance that the shaman displays his professional skill, but it is exactly in this connection that certain characteristic differences in technique are in evidence, indicating that historical influences may have been at work in the past in different ways. The researches of Thalbitzer have made it probable that a strong shamanistic wave reached America from Asia at a certain period. ${ }^{3}$ This seems to be confirmed by the archaeological finds made by Larsen and Rainey at Ipiutak (Pt. Hope). These include curiously carved swivels of walrus ivory which seem to be imitations of Asiatic shamans' equipment. ${ }^{4}$ It is true that corresponding elaborate objects have not been found outside Alaska, but on the other hand there is considerable

1 Lantis I946, p. 200.

2 Birket-Smith I953, p. 126.

3 Thalbitzer I928, p. 419 .

4 Larsen \& Rainey 1948, pp. I3I f. 
evidence that a more active form of shamanism has found its way to the Eskimos and has spread along the Arctic coast to Greenland, probably in connection with the neoeskimo Thule culture.

It is a characteristic feature of this form of shamanizing that the shaman makes extensive use of the drum when he works himself up into ecstasy and invokes his helping spirits. Here apparently also belongs the shaman's "spirit flight" (ilimarneq) with his arms and legs laced tightly to the body, besides a strongly dramatic appearance in general.

As distinct from this some Central Eskimo use a more passive and contemplative way of shamanizing, more suggestive of North American Indian shamanism. The shaman gets his visions sitting or lying in deep concentration at the back of the sleeping platform, behind a curtain, or covered with a skin. The drum is not used in this connection.

This less dramatic form was also known in Greenland but was said to have been used there only by shamans of inferior degree. It was called kilungmôrssorneq, "to go to the back of the platform", and the shaman himself was called nerfalassoq, "one who lies on his back". In Greenland no doubt it represents an older tradition that has been superseded by the more active form.

Besides these two characteristic forms which make special demands on the shaman's personality and training, a still more popular and simple method of invoking spirits exists, namely the so-called qilaneq or "head-lifting". It is known from all parts of the Eskimo world, where it is also sometimes practised by the professional shamans. The method is performed by alternately lifting and sinking a heavy object by help of a leatherstrap the other end of which is sometimes tied to a qila-stick. At the same time questions are put to a qila-spirit which is supposed to enter the object, or stay in the earth immediately below. In most cases the question is whether a sick person will recover, or the like. If the lifted object feels heavy it is mostly taken as affirmative, and negative if light. The lifted object is usually the patient's head or foot. Thus it can also be practised with oneself insofar as the foot is used. In some places, however, a rolled up coat is used, as in the particular instance of the Caribou Eskimos where the shaman uses his own coat, and lifts it by help of his shaman's belt and and the qilastick.

No doubt the Eskimo qilaneq dates back to a time prior to the more profes- 
sional shamanism. The circumpolar distribution of the method alone indicates a very great age. However, more conclusive seems to be that the wordstem qila is also found in the name for the shaman's drum, qilaut, literally "a qilaneq-instrument". Thus shamanizing with the drum seems to have been regarded as a new way of performing qilaneq.

Just as the general functions of the shaman are the same almost everywhere, his introduction into the profession and training also show great uniformity. Often it seems to have been a dream or some extraordinary experience of nature that has made a person think that he was called to become a shaman. He may try to resist, but in spite of a strong mental pressure he will perhaps in most cases yield to what he feels as destiny.

The next step usually will be that he approaches an older shaman, who may then take care of his further education. Sometimes there could be two teachers, sometimes more. In East Greenland for instance it was customary for the novice to consult several "specialists".

Before tuition could begin, it was always necessary to give a present to the teacher. The Iglulik shamans explained it as a gift to the future helping spirits even if, of course, in practice the teacher himself had the benefit of it. ${ }^{1}$ The instruction proper might last from a few days to several years. The latter was often the case in East Greenland. To some extent, however, it would depend on the novice himself.

It is a general feature that the novice should spend long periods in solitude, in desolate places where he expected to meet the beings who should afterwards serve as his helping spirits. Often he had to undergo the most severe sufferings from cold and hunger. In fact, in order to become an able shaman it was necessary to experience the mystery of life and death. This could be done in different ways. From the Caribou Eskimos for instance hanging, drowning, and shooting are mentioned.2

The most detailed descriptions of the shaman's "death-test" come from Greenland where the novice, hypnotized by constantly rubbing a stone in circles, was eaten by the mighty spirit who suddenly appeared as a bear from a lake and attacked him. He would fall into a faint and afterwards find

1 Knud Rasmussen i929, p. i i I.

2 Knud Rasmussen 1930, pp. $57 \mathrm{f}$. 
himself naked on the shore, but on his way home his clothing would come flying after him through the air.

A similar tradition is known from Labrador, ${ }^{1}$ and, on the whole, it seems that experiences of this kind have been known by most Eskimo groups. Thus, according to Knud Rasmussen, an Iglulik shaman must be able "to see himself as a skeleton" and name all the parts of his body, every single bone by name in the sacred shaman's language. ${ }^{2}$ This greatly recalls the "dismembering" of Sibirian shamans.

Also a kind of "worm test", reminiscent of American Indians' "ant test", has apparently been known by the Eskimos. By letting worms eat the meat from the body the shaman became "light and shining", as Knud Rasmussen was told in North Alaska. ${ }^{3}$ That the shaman is shining, or filled with an inner light, is a widely spread idea. In this way he was thought to be observed by his helping spirits. A "worm test" is also mentioned from the Aivilik Eskimos, ${ }^{4}$ and from West Greenland. ${ }^{5}$

A special interest attaches to the bear-figure Tôrnârssuk. By the early Greenland missionaries he was described as "the master of the helping spirits". This conception has been opposed by Thalbitzer, who, however, seems to some extent to have based his view on the particular conditions in East Greenland where in fact Tôrnârtik was only the most prominent helping spirit, and was clearly not identified with the bear-monster that eats the shaman to be. ${ }^{6}$ Thus it might seem as if a splitting up had taken place in East Greenland, the name of Tôrnârssuk (Tôrnârtik) having become transferred to the helping spirit, whereas his original nature of a supreme being still manifests itself in the mystic bear.

In West Greenland, however, it seems beyond doubt that Tôrnârssuk was really regarded as "the master of the helping spirits". It was he who gave the shamans "power" and provided them with helping spirits. The West Greenland Tôrnârssuk thus corresponds in all essentials to the mighty spirit who in North Labrador was imagined to live in an inaccessible moun-

1 Hawkes 19i6, p. 129.

2 Knud Rasmussen i 929, p. II4.

3 Knud Rasmussen (ed. Ostermann) 1952, p. I30.

4 Boas I 901, p. 154 .

5 Rink 1868 , p. 236.

6 Thalbitzer 1928 , p. 38 I. 
tain, and who controlled the game animals, allowing them to be hunted only on condition that the hunters treated them with respect and observed the prescribed rules. ${ }^{1}$ Similar ideas are found among hunting people in both North and South America, and seem to be characteristic of a very old stage of primitive hunters' culture.

Also with the Central Eskimos and in Alaska the Tôrnârssuk conception can be vaguely traced, and almost everywhere the bear is still regarded as a particularly strong helping spirit, even if as a real deity he has become relegated to the background by other powers. It may in this connection be significant that the shamans apparently nowhere get their "power" or "light" from the Sea-Woman. Caribou Eskimo Shamans get it from Hila or Pinga who controls the souls of the caribou. With the Iglulik Eskimos it is above all the Moon-Man, but also the Mother-of-the-Caribou, bears in human form, and deceased persons that are mentioned as sources of power. ${ }^{2}$

A helping spirit is generally called a tôrnaq, and the shaman himself angakkoq. Locally, however, also other names are found, e.g. apersaq, "one who is questioned", or nakorut, "something that gives strength". In Alaska the common name is tuneraq, and the shaman is correspondingly called tunralik, "one who has a tuneraq".

The helping spirits form a very mixed assembly. Here free reins seem to have been given to the imagination. Nevertheless certain more constant types are met with, thus in East Greenland where each shaman must try to get a tôrnârtik, an aperqit (asking spirit), an eqingaleq, a falcon, certain frightening spirits, etc., each of which could be charged with special tasks. During the séance the shaman would summon one or more of his helping spirits and speak with them in the special shaman's or spirit language, or he could let them enter his body while his own soul made flights far away.

Masks seem generally not to have been used at the séances proper. At cultic festivals in Alaska, however, it was not unusual that a shaman wore a mask representing a helping spirit, but also laymen could wear masks on such occasions.

Also dolls are mentioned. The Chugach Eskimo shamans are said to have owned special dolls in which they could let a helping spirit take up its

1 Hawkes I916, p. I29; Turner I894, p. 195.

2 Knud Rasmussen I929, p. I I3. 
residence before being sent out to perform some task or other. ${ }^{1}$ Similar dolls are known from the Copper Eskimos. They were made of bark and correspondingly called "kaisalluk" (cf. WGrl. qasaloq, "bark of a tree"). ${ }^{2}$

On the whole the professional equipment of the Eskimo shaman seems to have been sparse. Presumably each shaman had his own drum, and in some places a qila-stick. In East Greenland the shaman used besides the drum a makkortaq, i.e. a small rattling skin which he held on the palm of his hand and rapped with a stick. The Caribou and Iglulik Eskimo shaman wore a belt with attached amulets, or gifts that had assumed the character of amulets. Otherwise no special shaman's costume is known. It is, however, interesting to note that an Alaska shaman on certain occasions wore a gutskin coat, and the same is known from Eastern Central Eskimos. ${ }^{3}$ This custom apparently goes back to Asia, where Keretkun of the Chuckchee, the same as Kacak of the Eskimos, was imagined to wear such a coat which similarly was worn by all people when they participated in ceremonies performed in his honour.

\section{BIBLIOGRAPHY}

Birket-Smith, K. The Chugach Eskimo. Nationalmuseets Skrifter, Etnografisk Række, VI. København 1953 .

Boas, Franz, "The Central Eskimo." Bur. Am. Ethn. An. Rep. 6. г 888.

_- "The Eskimo of Baffin Land and Hudson Bay." Am. Mus. Nat. Hist. Bull. I5. I $901-1907$.

Bogoras, W. "The Chukchee." Am. Mus. Nat. Hist. Mem. I r. I9ıо.

Hawkes, E. W. "The Labrador Eskimo." Can. Geol. Surv. Mem. 91. No. 14, Anthropol. Ser. r 9 r 6.

Himmelheber, H. Eskimokïnstler. Stuttgart 1938.

Jenness, D. "The Life of the Copper Eskimos." Rep. Can. Arct. Exp. XII. Ottawa I922.

Kroeber, A. L. "The Eskimo of Smith Sound." Am. Mus. Nat. Hist. Bull. г2. 1900. Lantis, M. "The Social Culture of the Nunivak Eskimo." Trans. Am. Phil. Soc. n.s. Vol. XXXV, Pt. III. 1946.

—-Alaskan Eskimo Ceremonialism. Mon. Am. Ethn. Soc. XI. 1947.

Larsen, H. and Rainey, Fr. "Ipiutak and the Arctic Whale Hunting Culture". Anthr. Pap. Am. Mus. Nat. Hist. Vol. 42, 1948.

1 Birket-Smith I 953, p. 127.

2 Jenness 1922, p. 197.

3 Nelson I899, p. 432; Lantis I946, p. 203; Hawkes I9I6, p. I37. 
Nelson, E. W. "The Eskimo about Bering Strait." Bur. Am. Ethn. An. Rep. 18. I 899.

Ostermann. H. (ed.) Knud Rasmussen's Posthumous Notes on the Life and Doings of the East Greenlanders in Olden Times. MoG. Bd. 109 Nr. I. 1938.

— "The Alaskan Eskimos." Rep. 5. Thule Exp. X. 3. I952.

Rainey, Fr. "The Whale Hunters of Tigara." Anthr. Pap. Am. Mus. Nat. Hist. Vol. 41, Pt. 2. I947.

Rasmussen, Knud. Myter og Sagn fra Grønland. I. (I921), III. (I925). "Intellectual Culture of the Iglulik Eskimos." Rep. 5. Thule Exp. VII. I. I929. "Observations on the Intellectual Culture of the Caribou Eskimos." Rep. 5. Thule Exp. VII. 2. I930.

— "The Netsilik Eskimos." Rep. 5. Thule Exp. VIII. I93 т.

_ "Intellectual Culture of the Copper Eskimos." Rep. 5. Thule Exp. IX. I932.

Rink, H. "Om Grønlændernes gamle Tro." Aarb. for nord. Oldk. og Hist. 1868.

Rosing, Chr. Østgrønlænderne. Grønl. Selsk. Skr. XV. I946.

Rosing, Jens, Sagn og Saga. København I963.

Spencer, R. F. “The North Alaskan Eskimo." Bur. Am. Ethn. Bull. I7I. 1959.

Thalbitzer, W. The Ammassalik Eskimo I-II. MoG. 39 (I914), 40 (I923).

_- "Die kultischen Gottheiten der Eskimos." Archiv für Religionswissenschaft XXVI. I928.

Turner, L. M. "Ethnology of the Ungava District, Hudson Bay Territory." Bur. Am. Ethn. An. Rep. I I. I894. 